\title{
The Philosophical Dimension of the Islamic Illumination in Designing Qur'anic Manuscripts
}

\author{
Fuad Eyad Fuad Khasawneh (Ph.D) \\ The University of Jordan, School of Arts and Design, Department of Visual Arts
}

\begin{abstract}
The philosophical dimension that was followed by the designers of Qu'ran manuscripts is considered in general a keystone in making the Qur'an scripts in the Islamic world. This moral philosophical dimension was later on deemed as principles for its design in manufacturing the sacred script. Accordingly, Illumination was used as an agent for building the art of writing, covering, lining as well as other arts that represent to main structural principles in making the Islamic script that is used as a profession for making codicology and in studying the material holder not to forget its symbolic dimension without taking account to the content. This study aimed at examining the philosophical dimension of using Islamic Illumination that is deemed as one of the main structural principles in designing the Islamic manuscript as well as its technology which is considered a field that distinguishes the research as one of the structural basis in designing the Islamic book, since Illumination as a feature to designing the Islamic book due of the beauty, design value and the sacred content. In this study, the researcher examines this philosophical and symbolic dimension as well as the principles and techniques which the craftsman used in using Illumination as designing principles to divide the page and space to add the Qur'anic sacred text in the Qur'anic scripts and introduces it in terms of using a sacred content. The researcher studies a sample of Qur'anic pages that refer to various Islamic ages, analyzed them, studied the design structure, the technique and the philosophical dimension of Illumination. The study concluded that Illumination was introduced to the Qur'anic script in order to create dignity and to show the greatness of God, not to forget the Illumination dominated on the Qur'anic script for the purposes of completeness, were it was introduced in the Qur'anic text to open a moral/ spiritual way for the one who works in designing the scripted Qur'an holly books.
\end{abstract}

Keywords: The Philosophical Dimension, of Illumination, Script, The Sacred Art.

DOI: $10.7176 /$ JTHS/47-04

Publication date: February $29^{\text {th }} 2020$

\section{Introduction}

As the case with the arts of Islamic book, such as Arabesque and lines, the art of Illumination was introduced so as to make ornament as a beauty, functional and a philosophical introduction in the design of the scripted Qur'ans. In this context, using melted gold as used as an ink in writing the Qur'anic text and to improve and honor the writing of the Qur'ans, despite the fact that at the beginning, it was limited and restricted in decorating the division of the holly Qur'an text such as separators of the (Sora) and to separate the (Aya), (Ahzab), parts and beginnings of the Qur'an, which are all considered as aspects of the structural principles in the design and organization of the Qur'an. Later on, this use was developed to include the design of first pages of the Qur'an and the Qur'anic text.

In this regard, using Illumination in the Islamic arts used widely used; it was used in architecture, crafts, books and other arts until it became a feature that distinguish Islamic arts from other sacred and life arts. Some people stated that such use is a kind of sacredness of the artistic content and symbolism, resulting is using the art of Illumination in the design and beauty of Islamic arts.

Hanash believes that researching in the field of Islamic Illumination was restricted as a beauty feature or a secondary craft as a part of Islamic representation of scripts (Hanash, Idham 2010). Accordingly, research in the field of Islamic Illumination only provided us with a historical descriptive study without shedding light on its feature as structural and philosophical principles in the design of old Islamic scripts.

In this study, the researcher attempts to study Illumination as philosophical and symbolic dimensions as one of the structural principles that were used in building, decorating, organizing and preparing the Qur'anic script as a container to write the sacred Qur'anic text.

Consequently, this study starts to ague that Illumination plays a significant role in decorating the texts of the holly Qu'ran, where some studies indicate that such art is deemed as a pure ornamentation without differentiation between it and other ornamentation arts. As a result, the researcher introduced in this study the principles, aspects, techniques and the philosophical dimension of Illumination.

\section{Statement of the problem}

This study intended to uncover the philosophical dimension of Illumination in the Qur'anic texts. This can be attributed to the fact that Illumination plays a significant role in the design structure of Islamic scripts, a reference of beauty and a symbolic philosophy that has attractiveness of psychological factors, not to forget the 
ability to show the context and its importance, with sacredness of such content that is deemed words of God and a source for religious jurisprudence (Tashree').

\section{Purpose of the study}

Uncovering the philosophical symbolic dimension and the principles, techniques and methods of Illumination in the Qur'an texts as well as their ability to transmit a designer, visual and spiritual vision in the design of the scripts, not to forget showing the importance and spiritual dimensions on the intellectual, artistic technical levels.

\section{Significance of the study}

The significance of the study comes from the need to know Illumination as a philosophical, symbolic and spiritual dimension in designing the Qur'anic scripts and to introduce its beauty features that refer to its design method.

\section{Methodology of the study}

This study relies on the descriptive, analytical and historical methodology which fit with its purposes that intend to study Illumination and it philosophical and structural dimensions while showing its importance and dimensions of beauty on the intellectual, artistic and technical levels.

\section{Limitations of the study}

Place limitations: including samples of written holly Qur'an books.

Time limitations: studying of some Qur'anic pages of Qur'ans that were written during the period from the third century, till the eighth century of Hijra timing.

\section{Pervious studies}

A study conducted by Hanash, Idha (2010), titled: the Islamic Illumination: the historical principles and classification basis. The researcher use the descriptive methodology and studies Islamic Illumination, techniques, methods and it symbolic philosophy. The study concluded that Illumination is one of the main principles in the Islamic scripts and is used in the texts for ornamentation and beauty purposes.

A study conducted by Al-Husseini, Hashim (2011) titled: features of Illumination techniques in the written texts. The researcher used the descriptive methodology and studies Islamic Illumination, techniques, methods and history. The study concluded that Illumination is used in the Islamic crafts and scripts for ornamentation purposes.

\section{Literature review}

\section{Illumination in language}

God almighty says: (They are embroidered with bracelets of gold and pearls) "Fatir Sora, verse 33). The meaning of Illumination is taken from gold, and the piece is a golden one. It could be feminine and masculine. The golden is the thing which is covered with gold, and (Thahabia is the small part of gold). It was taken from the saying of Ali (peace be upon him, saying: he sent a golden piece from Yemen). The plural is (Athab and Thuhoub). Ali says: if God wanted to open golden treasure for them he would have done that). The golden thing is the object that is plated with gold (Abu al-Fadl, Jamaluddin, 1988).

The term (gold) was mentioned many times in the holly Qur'an. God says: if a golden bracelet was thrown to him or angels came with him chained) "Al-Zukhruf Sora, 53). God is well-known, and a piece thereof is (Thahaba); Mathahib is belts plated with gold and everything decorated with gold in golden, the subject is (Muthhib, Ethhab and Tathheeb are the same, which mean plating in gold (Al-Jawhary, Ismail, 1990).

\section{Illumination in terminology}

The art of Illumination is an artistic type for presentation through the liquid of gold. It is said that it is an artistic way in covering the script and to make ornamentations using a shining golden paint (Banin, Shawqi, 2003). In the books, Al-Qalqashandi (Al- Zarkaly, Khairiddin, 2003) described gold plating as a solution of gold liquid that is mixed with water, glue and lemon juice and gives a golden shining for the shapes (Al-Qalqashandi, Abu Al-Abbas, 1922). Gilding has various methods mostly when the liquid gold is poured on something and plates (Banin, Shawqi, 2003).

\section{Illumination as a structural basis and a philosophical dimension}

Talking about Islamic Illumination mostly relies on the study of the scripted Islamic book and mainly on its material shape which as indicated before comes under the title (Codicology), which means studying the basis structural aspects of a book regardless of its text or subject. Here, we do not mean studying what relates to the main text of the book, but it means that such science studies the form, design and artistic feature on which the 
written book relied, including the art of Illumination.

The simplest way to define this kind of art is that it is an artistic one through using the solution /liquid of gold. It is said that it is an artistic way through covering the script and its ornamentations with shining golden paint. Al-Qalqashandi (in Subh Al-A'asha) stated that it is a solution of gold filling mixed with water, glue and lemon juice, which produces a golden shining for the objects that use it.

Accordingly, Hanahs stated that Illumination in the Islamic Arab knowledge is a key aspect of this craft and one of the arts used in the Islamic books. In addition, it is a process of coloring by golden color, showing the distinguished art of the shapes, photos and scripts/ writings in the books, in addition to being a cultural traditional craft for coloring and embroidering (Hanash, Idha 2010).

The manuscript Islamic book is the only book with which the art of Illumination is related since its establishment, especially the scripted Qur'ans in particular, despite of the negative attitude of the Muslims towards using the art of Illumination in the first centuries. In addition, Sajistani states that Illumination in the holly book (Qur'an) consisted of two main stages, first: care and fear of the reactions of exaggeration in copying the holly books on the separators of Sora and Aya/verse (Sajistani, Abu Baker, 2002). Fear was not taken based on a legal religious objection or prohibition, but fearing of what other or extorter calls for.

However, this does not prevent using gold in early stages, as the first Tathheeb of the Qur'ans refers to the second Hijra century. Ibn Al-Nadeem (Othman, Abbas, 1978) discusses the use of Tathbeeb in the early Qur'ans, such as a Qur'an that is attributed to Imam Ali Bin Abi Talib (peace be upon him) which is kept in Toub Qabu museum. The names of Sora were decorated/ plated with gold. The biggest evidence in the art of Illumination was present at the end of the second Hijra century, with what is known as the blue Qur'an. It is the older evidence. However, with the beginning of the third Hijra century, Muslims began to use Illumination in the scripted book especially the Qur'ans. Al-Maqrizi states that there are more than one thousand Illuminated copies kept in the treasure of books of Al-Azeez Billah Al-Mustansiri. During the fifth Hijra century, Illumination was used mainly in the scripted Qur'ans.

A feature that distinguishes the art of Illumination in the Islamic civilization from other civilizations was the Muslims reliance on writing with golden water; the text was sacred which called Muslims to write it in gold to glorify God. As for Illumination of Arabesque and separators, they were used on a secondary basis, contrary to other civilizations where Illumination of books relied on Illumination of the Arabesque.

The oldest method which Muslims followed in the Illumination of the scripted books is to stick golden chips on the desired locations, through cutting them on a form of letters or shapes. This is a difficult process and inaccurate while it needs a sticking/gluing agent to complete it. Later on, Muslims began making gold liquid during the seventh Hijra century. Al-Qalqashandi, Abu Al- Abbas, 1922) urge that golden liquid / ink was made through melting golden chips in lemon juice then pouring pure water on the mixture. The particles of gold precipitate and then they are mixed with saffron and some liquid to become ready to be used in writing. This method makes liquid/ ink upon writing thick and clear and thus needs a polishing process after it becomes dry. There are other methods which were used later through crushing gold to become a soft powder then plant glue is poured (called Leck water). After that, water is poured to wash it, when its forms becomes like honey, it becomes ready. Afterwards, Muslims began making golden ink/liquid using different materials due to the high cost of gold. Syndrous, saffron, arsenic, turmeric, Borq and other substances were used to make golden liquid/ink. Muslims gave attention to the Qur'ans through the method of making golden ink/liquid where egg yellow is taken and put in arsenic for two weeks and when it becomes dry, it is put on fire and moved to become solid, then put in a container and crushed and mixed with Saffron then becomes ready for writing.

Ibn Badis stated in Omdat Al-Kutob and the Eddah of the intellectuals, the method of making golden ink, which consist of red arsenic, saffron and water to obtain golden ink. He urged that different raw materials are used in making golden ink such as Asphidag, Marara and the papers of anemone.

The use of golden ink in the Qur'anic scripts with its various raw materials was one of the structural principles in designing the Qur'anic scripts. This process uses different methods in using ink and adding it on the text. In this regard, Illumination was related with different aspects inside the Qur'anic script. Accordingly, at the beginning it was used in the separators, beginnings of the Sora and then into the Qur'anic text and then Illumination was used as a main basis in designing the pages of the beginning which was known as (the secret of the page). This aspect gained high attention in making the Qur'anic scripts due to its philosophical and symbolic dimensions that make it an introduction and a gate to the holiness of the Qur'anic texts. Illumination and its respected rank (beauty and moral) (Hanash, Idham, 2010) is largely found in various Qur'anic scripts, especially in the writing, divisions of the pages and the secrets of the page. This is considered as a spiritual and beauty introduction that carries the worshipper into a spiritual special and holly world. On the other hand the issue of Illumination is preferred on other Islamic arts in the scripted Qur'ans where Illumination mainly was introduced to enhance beauty and symbolization aspects. Here, Illumination is the main and most eminent, in terms of the shape, function, color, value and symbol wherever found in the artistic work, though such beauty and indicative presence of the art of Illumination can not be imagined without an agent of other Islamic arts, such as writing, 
Arabesque and other arts.

Furthermore, Hanash, Idham (2010) believe that the main theme of the philosophical dimension focuses on the (light), which is deemed the upper value in the Islamic beauty were it is also considered the spiritual and indicative source that gives the script the value of beauty and adds honor as well as the artistic and indicative dimensions.

The symbolic and spiritual philosophy of using Illumination in the arts of the Islamic book stems from the holiness and glorifying of God's words whether by the subject, technique or color. It was not a kind of luxury or wasting but it largely contributed in distinguishing the design of the Qur'anic script. We will observe this clearly in the samples used in this study.

\section{Artistic Illumination methods}

Muslims were skilled in the techniques of Illumination; such techniques varied depending on the implementation method that is applied and used more than one method for Illumination. among the most important techniques are the (Zarfishan or Tarmil with gold; which an artistic technique the relies on throwing gold on the script through what is called (Mirqash). This method depended on the melted gold (Dirosh, Franswa, 2005), where gold is thrown on the paper before or after writing thereon. Another technique is used by using a sack that contains small hales through which the powder of gold is sprayed on the paper that was glued in advance. This Illumination method goes back to the 8th Hijra century of Bilad Faris (Persia).

The second technique is called (Takfeet) which is given to the clothing and studding and precipitation. It refers to covering the raw material after gluing. In addition, it is a process of fixing gold in the various raw materials after gluing, then spraying the powder of gold on the written or decorated area which is glued, too (Hanash, Idham, 2011). After that, the sticking process takes place to get rid of the edges and bulges.

The third technique is called (Tazmeek) or (Tash'eer); it is a special kind of Illumination. (Zamak) is inserting the things in each other. It a process of amending and defining the writing through filling the gaps that is established of the process of Illumination. This means filling the edges by a pen. It is said (Yozammikah), which mean a process used to define the border of letters but not necessarily that ink should be golden. By (Tash'eer) it makes the borders and the best example for the (Tazmeek) process is a scripted Qur'an that is kept in Itanbul library that was made for Sultan Nassir Bin Qalawoon (712 H 1313). It was implemented (Zamked) by Ali Bin Mohammed Al- Rassam, who was known as the (left-handed) (Sayyid, Ayman, 1997).

The art of Illumination is in original one linked with the various Islamic arts like photography, ornamentation, writing and a non-dividable part of the Islamic arts spectrum. It was established and grew under the Islamic civilization and largely contributed in putting the basis of making Islamic books which gave it a role to show the beauty and function and spiritual work. Its industry was unique by finding chemical formula for its ink, to grant it dignity, and the Islamic civilizations were skilled in using various techniques in the art of Illumination preceding other civilizations.

\section{Analysis of the sample}

\section{The first sample:}

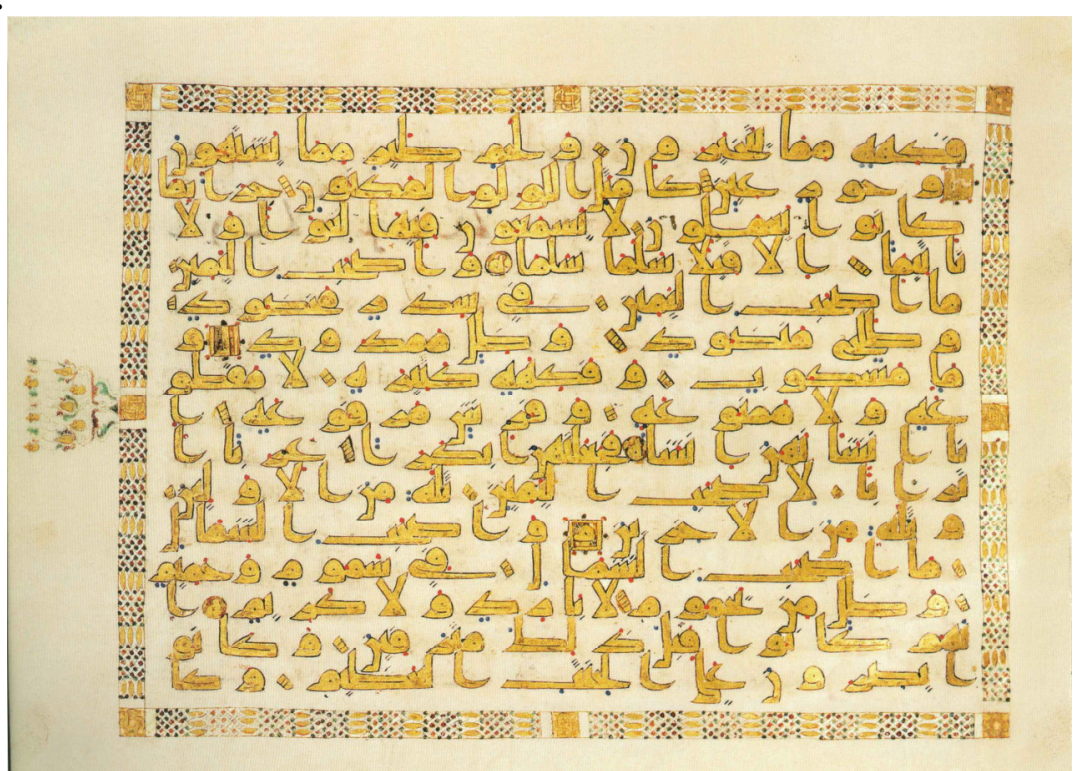

A paper of the Qur'an written in the old golden writing on skin papers $(27 \times 37 \mathrm{~cm})$ that goes back to the 9th calendar century. 


\section{Analysis}

In the scripted Qur'an papers we note that it was fully designed by using the art of Illumination where the manufacturer began defining the margins and text space through a decorated design using golden ink so as to define the space for writing. It was defined in a form that is appropriate with the papers of the skin and the same applies for the margins on the side of the skin. Later on, this space was replaced by lining which became a unique art. Such use of the golden frame and the forming (like a tree) that refers to the philosophical dimension is taken from the holly verse: Haven't you seen how God presented an example of a good word as a good tree with its roots are fixed and its branch is high in the horizon (24).

It is worth stating that most of the golden ornamentations used in the Qur'an texts are quoted from the tree, which also come from the symbol of the good word that indicate to the holiness of the text and its source (from God Al-Mighty). In addition, we notice that the manufacturer's use of golden ink in writing the Qur'anic text that was written by using the old writing, used the Tazmeek technique where he introduced the golden text through golden in inside a pre-defined frame for writing. That kind is deemed as a type of honor for the sacred text and to show the lighting of the text and its ornamentation. The design structure of the text was consistent where the start and end make a fixed and stable rectangular shape, where Illumination showed the relationship with fear and good manners not to forget showing God's greatness. Since Muslims were always looking for completeness regarding the sacred content, then the idea of completeness fully dominated the manufacturer stems from the idea (the idea of all/ completeness) and unity of all, the golden text and ornamentation were means to show God's completeness and sacredness.

\section{The second sample}

A qur'an's paper in Morocco writing on papers $(17,5 \times 19 \mathrm{~cm})$ that goes back to the 13 th calendar century.

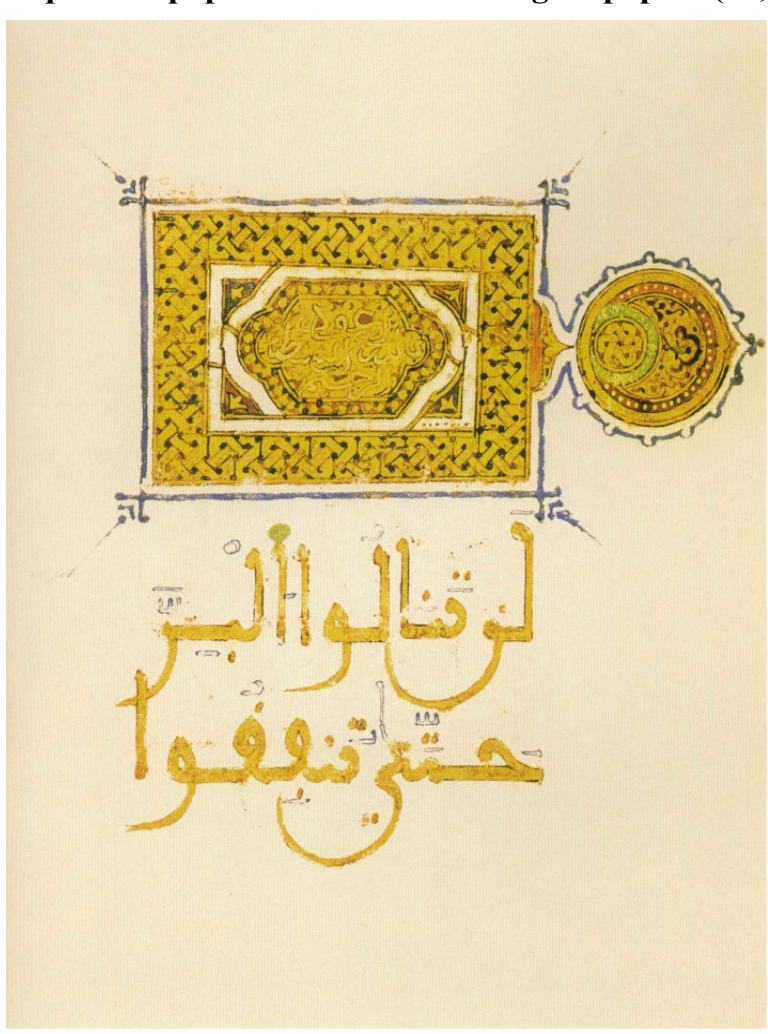
Analysis

In the papers of the script, we notice it was designed completely by using the art of Illumination, where the manufacturer began defining separators of the Sora (an engineering rectangular design, and from the introduction and beginning presenting a circular form. Bellow that comes the Qur'anic text using the Moroccan script which was plated with golden ink. The separators of the Sora were golden of an ornamentation that is connected together using golden color that surrounds a religious text (I pray to God to protect me from the cursed Satan).

This form helped in dividing the page and prepare it to add the text consistent with the opposite pages taking into account the margins and space to show the design on its best forms. As for the philosophical dimension, Sora separator was like a kind of protection and introduction to the Qur'an text, which surrounded the text (I pray to God to protect me from the cursed Satan) through using the Tazmeek technique as the make used golden ink to write the full text. This intends to honor and as a symbolization of the sacred texts. On the other hand, using Illumination in the art of writing and ornamentation came to honor such arts and to show the sacred dimension within them. Moreover, the role of the sacred art here is a means to present God's presence and completeness, while the philosophical and spiritual purpose of Illumination is to show the highest and deepest dimension of the religious text. 


\section{The third sample}

A paper of the Qur'an written in Rihani writing with titles of Sora in white and the writing $(26 \times 37 \mathrm{~cm})$ that goes back to the 8th $H$ century (14th calendar century).

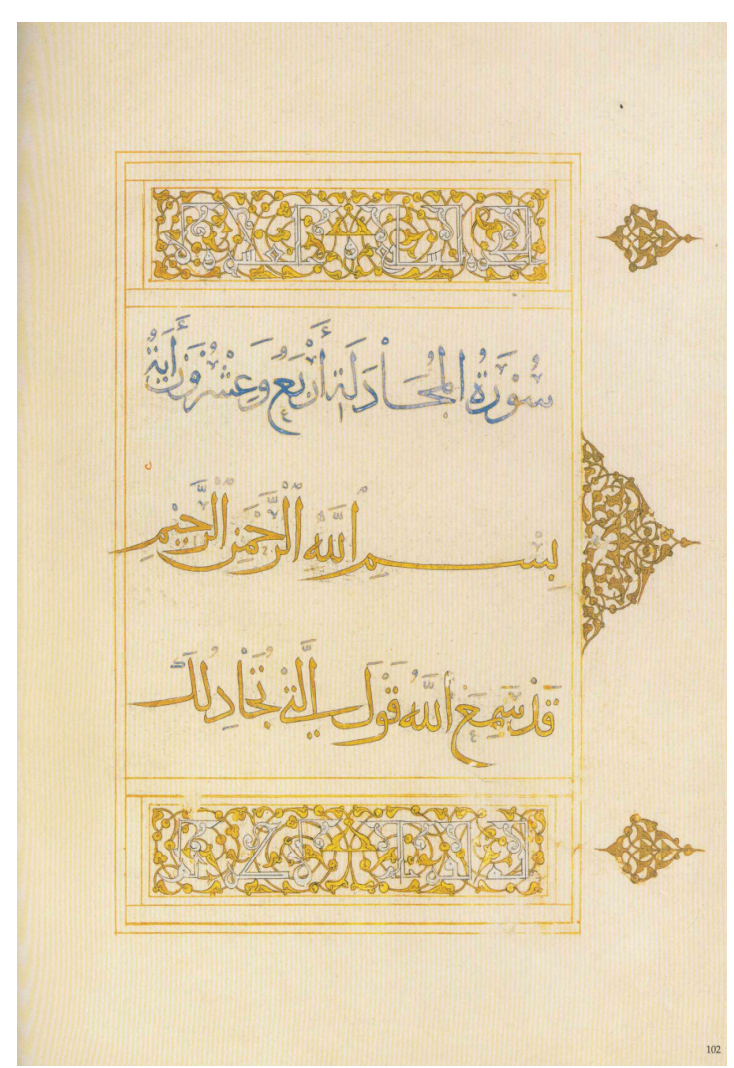
Analysis

In the script, we notice that it was fully designed by using the art of Illumination as the maker began with a rectangle divided into three parts; the upper contained a rectangle plated with gold. On the top of the page it has (the part) and then down there is a rectangle that defines the space for writing the text (the name of the Sora and dark color while the Qur'anic text was plated with golden liquid using Tazmeek technology, with a lower rectangle that contained a religious text written white inside a golden ornamentation. The rectangle is surrounded (from the right part) with three suns of papering golden ornamentation,

Which was mentioned before and we talked about the philosophy of the tree form in it. In addition, we observe the use of gilding in the design structure of the Qur'an as a whole where it was used initially in the design of the page, the division of text and space as well as using it in the Quranic text and in the moles that surround the text. Furthermore, we note the coherence of the design as one structure and the formation while taking space into account. As a part of the design, the separator of the fence, which came with a rectangular geometric design, protrudes from the foreground a gilded solar composition, and beneath it is the Qur'anic text using the Moroccan Kuffi script interlaced with the use of a gold outrigger. The idea of perfection was saturated by the idea of the whole in design, where the different parts are linked to the unity of the whole, i.e. unity and diversity within the same page, where the use of ornamentation, calligraphy, securitization, dividing the page and margins, so all these different arts were used through unity for all.

\section{The forth sample}

A paper of the Qur'an in the golden writing (57 x $40 \mathrm{~cm})$ that goes back to the year $710 \mathrm{H} / 1310$ calendar.

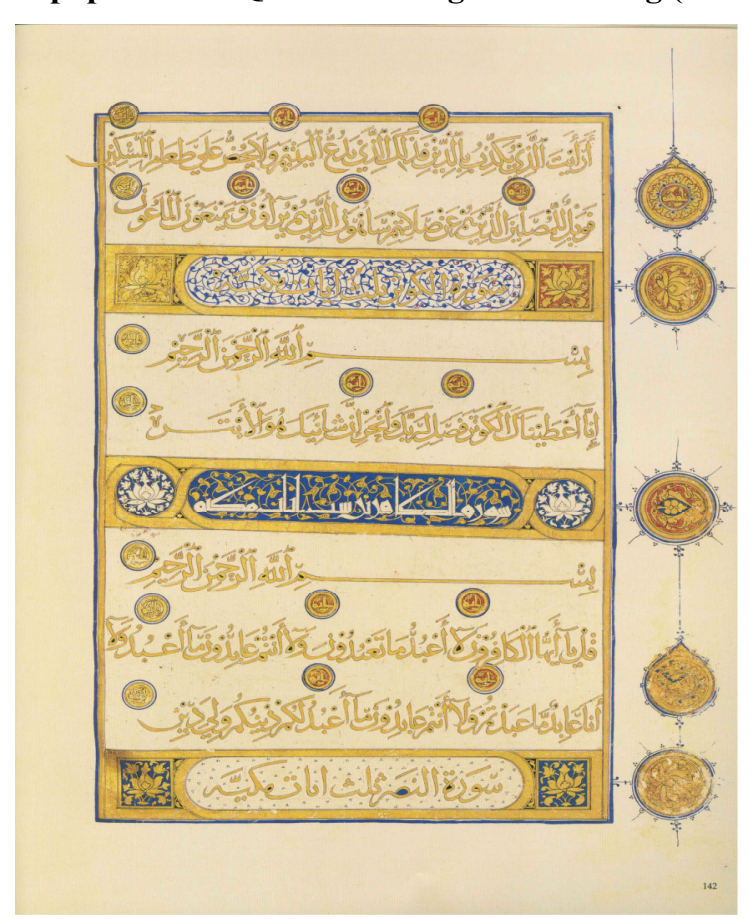
Analysis

In the scripted paper we notice that it was fully designed by using Illumination, where the manufacturer began designing the page with a longitudinal rectangle divided into a ser of rectangles to define the separators of Sora and the space of the Qur'an text, taking the space of margins and the umbrellas of the parts and Ahzab into account. As the case with the Islamic design, we observe that the manufacturer considered the gold percentage in dividing the rectangle. The philosophical dimension indicates to the domination of the idea of completeness on the manufacturer, who used golden ink in writing the Qur'anic text considering it as a light or an Illumination or a symbol of light, which is clearly noted in the design of this page where he used Illumination in all words of the page. In addition, we observe a balance inside the page between the separators of the verses and the Qur'anic text from one side and between the separators of the Sora and the umbrellas of Ahzab, from the other. The golden Qur'anic text opens a spiritual road for the one who works in Illumination that enable him produce a non-finite presence in the design. Such a presence gives the Qur'anic text an honor and sacredness. 


\section{Conclusion}

It seems that the Islamic Illumination was one of the main aspects in the design of the Qur'an books (the scripts). Accordingly, Illumination appeared as a main theme to show the sacredness of the content through a series of design principles such as ornamentation, papering, lining and division of the page as well as other design principles on which the pages of the Qur'anic script relied. However, as a philosophic dimension, Illumination played an important role in showing completeness through presenting the relationship of part with whole, unity and variation. Accordingly, Illumination contained all kinds of arts and represents the main unity through the variation of arts as an agent. Islam is dominated by the idea of completeness, which is saturated with the idea of unity. From a philosophical perspective, Illumination is related with fear and good manners that show the sacred text and God Glorification. The symbolism of lighting of the text Illumination was used in relationship with the light, where the sacred text was shining and lighting. However, the symbolism of light was evident in the sacred text. On the other hand, the symbolism of the tree was evident through separations of the verses not to forget its beauty and functional dimension. The sacred text opens a spiritual road for the one who works in Illumination in a way that allows him to launch an ever-lasting presence. The main purpose of Illumination is to call the deepest dimension of the text; Illumination and its beauty and sacred presence plays a significant role in the structure of designing the scripted Islamic book.

\section{References}

Ibn Nadeem, Abu Al-Faraj Mohammed Bin Ashaq Bin Abi Ya'qoub Al-Nadeem Al-Warraq Al-Baghdadi (1978), the index, investigated by Nahid Abbas Othman, Ed. 2, Dar Al-Ma'refa Printing \& Publishing, Beirut, Lebanon.

Ibn Manthour, Jamal Eddin Abu Al- Fadl (1988), Lessan Al- Arab, Ed. 1, Dar Ehya' Al-Turath Al- Arabi printing, publishing and distribution, Beirut, Lebanon.

Al-Husseini, Hashim, Feature of the techniques of Illumination in the written scripts, (2011), Al-Academy Journal, Vol. 60, Baghdad University, Iraq.

Al-Jawhary, Ismail Bin Hammad (1990), Al-Sihah Fi Al-Lughah, investigated by Ahmed Abdul Ghafour Attar, Ed. 4, Dar Al-Ilm Le- Imalayeen, Beirut, Lebanon.

Al- Sajistani, Abu Baker, Abdulla Ibn Abu Dawood (2002) Kitab Al-Masahif, investigated by Muhibuddeen Wa'iz, Ed. 2, Dar Al-Basha'ir Al-Islamyia, Beirut, Lebanon.

Al-Fairouz Abadi, Mohammed Bin Ya'qoub, Al- Qamous Al-Muheet, investigated by Mohmmed Na'im AlIrqsousi, Ed. 3, Egyptian Corporation for writers, Cairo.

Al- Zarkaly, Khair Edeen (2002), Al-A'lam, translations' Dictionary, Dar Al-Ilm Le- lmalayeen, Beirut, Lebanon.

Al - Qalqashandi, Abu Al- Abbas Ahmed 1922), Subh Al-A'shar Fi Kitabat Al-Insha', the Egyptian Book House, Cairo,

Banin, Ahmed and Tobi, Mustafa (2003), dictionary of the terms of the Arab script, Ed. 1, The National Printing and paper house, Morocco.

Hanash, Idham (2011), an introduction for studying Islamic Illumination and basis of classification, Al-Academy journal, Vol. 55, Baghdad University, Iraq.

Hanash, Idham (2010), Islamic Illumination, historical perspectives and principles of classification, Al-Academy journa, Vol. 55, Baghdad University, Iraq

Sayyid, Ayman Fuad (1997), The scripted Arab book and the science of scripts, the Lebanese Egyptian House, Cairo.

Deroutch, Franswa (2005), introduction to the science of the book scripted in Arab letters, translated by Ayman Fuad Sayyid, Al-Furqan Al-Islami Est., London. 